IZA DP No. 8468

The Brazilian Wage Curve:

New Evidence from the National Household Survey

Badi H. Baltagi

Bartlomiej Rokicki

Kênia Barreiro de Souza

September 2014 


\title{
The Brazilian Wage Curve: New Evidence from the National Household Survey
}

\author{
Badi H. Baltagi \\ CPR, Syracuse University and IZA \\ Bartlomiej Rokicki \\ University of Warsaw and REAL, University of Illinois \\ Kênia Barreiro de Souza \\ CEDEPLAR/UFMG and REAL, University of Illinois
}

Discussion Paper No. 8468
September 2014

\author{
IZA \\ P.O. Box 7240 \\ 53072 Bonn \\ Germany \\ Phone: +49-228-3894-0 \\ Fax: +49-228-3894-180 \\ E-mail: iza@iza.org
}

\begin{abstract}
Any opinions expressed here are those of the author(s) and not those of IZA. Research published in this series may include views on policy, but the institute itself takes no institutional policy positions. The IZA research network is committed to the IZA Guiding Principles of Research Integrity.

The Institute for the Study of Labor (IZA) in Bonn is a local and virtual international research center and a place of communication between science, politics and business. IZA is an independent nonprofit organization supported by Deutsche Post Foundation. The center is associated with the University of Bonn and offers a stimulating research environment through its international network, workshops and conferences, data service, project support, research visits and doctoral program. IZA engages in (i) original and internationally competitive research in all fields of labor economics, (ii) development of policy concepts, and (iii) dissemination of research results and concepts to the interested public.
\end{abstract}

IZA Discussion Papers often represent preliminary work and are circulated to encourage discussion. Citation of such a paper should account for its provisional character. A revised version may be available directly from the author. 
IZA Discussion Paper No. 8468

September 2014

\section{ABSTRACT \\ The Brazilian Wage Curve: New Evidence from the National Household Survey}

This paper reconsiders the Brazilian wage curve using individual data from the National Household Survey at 27 Federative Units over the period 2002 - 2009. We find evidence in favor of the Brazilian wage curve with an unemployment elasticity of -0.08 when the lagged unemployment rate is used as an instrument for current unemployment rate. We also find that males in Brazil are significantly more responsive to local unemployment rates $(-0.13)$ than their female counterparts. In fact, we find that the unemployment elasticity for women is statistically insignificant. Applying gender specific unemployment rates, the elasticity for men decreases to -0.09 , while the elasticity for women remains statistically insignificant. This paper also finds that the estimates for Brazilian wage curve are completely different for the case of formal and informal workers.

JEL Classification: $\quad$ C26, J30, J60

Keywords: $\quad$ wage curve, fixed effects, regional labor markets, household surveys, informal workers

Corresponding author:

Badi H. Baltagi

Syracuse University

Center for Policy Research

Syracuse, New York 13244-1020

USA

E-mail: bbaltagi@maxwell.syr.edu 


\section{Introduction}

Since the pioneering studies by Blanchflower and Oswald (1990, 1995, 2000), the number of papers analyzing the wage curve has been constantly increasing. As a matter of fact, Blanchflower and Oswald (2005) report the existence of the wage curve for more than 40 countries. Yet, the majority of them are either European countries or developed economies. Blanchflower and Oswald (2005) find an unemployment elasticity mostly in the neighborhood of -0.1. Although, in their meta-analysis paper, Nijkamp and Poot (2005) claim that after controlling for publication bias, the 'true' wage curve elasticity at the means of study characteristics is no more than -0.07 .

This paper reconsiders the wage curve for Brazil - the biggest economy in South America and one of the biggest in the world in terms of nominal GDP. We use individual data from the Brazilian National Household Survey ${ }^{1}$ for the period 2002-2009². After excluding the selfemployed or paid family workers, the unemployed, inactive and missing observations, we are left with over 739,490 observations. The literature on the wage curve in other South American countries is rather limited and include papers on Argentina (Galiani, 1999), Chile (Berg and Contreras, 2004; Garcia and Granados, 2005), Colombia (Arango et al., 2010; Ramos et al., 2009) and Uruguay (Bucheli and González, 2012). Almost all of these studies rely on microdata and report unemployment elasticities around -0.1 . The only exception is the paper by Galiani (1999) who claims that the short-run unemployment elasticity in Argentina is below 0.1 , but approaches -0.1 in the long-run.

Previous literature on the wage curve for Brazil includes Garcia (2002), Souza and Machado (2004), Reis (2006), Santolin and Antigo (2009) and Silva and Monsueto (2012). All of these studies use the same survey (Brazilian National Household Survey). All find support for the existence of a wage curve for Brazil. For the period 1981-1999, Garcia (2002) uses individual

\footnotetext{
${ }^{1}$ In portuguese “Pesquisa Nacional por Amostra de Domicílios” (PNAD).

${ }^{2}$ The National Sample Survey (PNAD) is obtained annually except for Census years. The last two censuses were conducted in 2000 and 2010. So, the period 2001 to 2009 is the largest and most recent annual information sequence.
} 
data and applies a two-step regional fixed effects estimation procedure (an adaption of Card, 1995). He finds an overall elasticity of -0.13 . This unemployment elasticity is higher for women than for men, for non-whites, for non-household heads, for workers without a job contract; for part-time jobs and for younger workers.

For the same period and with similar methodology, Souza and Machado (2004) estimate an unemployment elasticity estimate of -0.23 for urban areas and -0.06 for rural areas, a clear reflection of the concentration of informal jobs with low payments in rural areas. Reis (2006) uses aggregated data for the 1990-1999 period in order to estimate a dynamic wage curve for different skill levels. He finds different elasticities for low (-0.05), medium (-0.04) and highskilled workers (-0.01).

Santolin and Antigo (2009) apply a dynamic pseudo-panel model estimated with Generalized Method of Moments for six Brazilian metropolitan regions over the 1997-2005 period. They aggregate the data for ten different groups by gender, race, age and education. They find an elasticity of -0.15 for the full sample, but the value goes down to -0.05 when only formal workers are considered. Their results also show that men have a higher unemployment elasticity than women, and that these elasticities decline over time. More recently, Silva and Monsueto (2012) analyze the wage curve for different segments in the labor market over the period 2002 and 2009. Applying individual data and following the Card (1995) approach, they find an unemployment elasticity estimate of -0.047 .

In general terms, previous findings for Brazil can be summarized as follows: i) there is a wage curve for Brazil; ii) the unemployment elasticity declines from the 1990s to the 2000's; and iii) less educated, informal workers, and males are more sensitive to regional unemployment rates. This paper contributes to the Brazilian wage curve literature in three ways. First, it estimates the Brazilian wage curve using rich individual data and not averages across regions. It controls for regional fixed effects and corrects for possible endogeneity of the unemployment rate using its lagged value as an instrument. Second, the data used is the most recent available data, accounting for changes in the labor market in the last decade. Last, we focus on robustness of these results to gender-specific unemployment rates and to how they differ across formal and informal workers.

These robustness checks turn out to be particularly important for Brazil, where the informality is around $27 \%$ for all workers, $29.86 \%$ for women and $24.80 \%$ for men, according to the 
Brazilian National Household Survey for $2012^{3}$. Also, Barros et al. (2011) report that between 1990 and 2007 the female labor force participation increased from around 40\% to more than $60 \%$. However, women are mostly concentrated in part time jobs, least productive sectors, with lower wages, and in the informal jobs sector (The World Bank Group, 2014). These characteristics make women a more vulnerable group in the labor market, and even worse off when employed in informal jobs.

The remainder of the paper is organized as follows. In Section 2 we briefly review the theoretical framework and the data. Section 3 discusses the empirical wage curve results obtained with region specific unemployment rates for all workers as well as gender specific regional unemployment rates. Section 4 focuses on the formality of employment and its impact on the wage curve estimates. Finally, Section 5 concludes.

\section{Theoretical framework and data}

The wage curve is simply a standard wage equation normally used to estimate the returns to education or the male-female wage gap but with the addition of the local unemployment variable to the set of regressors. Following Blanchflower and Oswald (1995), we estimate the augmented Mincerian (Mincer, 1974) wage equation in the form of:

$$
\log W_{i r t}=\alpha+\beta \log U_{r t}+X_{i r t}^{\prime} \gamma+\mu_{r}+\lambda_{t}+v_{i r t}
$$

where $W_{\text {irt }}$ is the real hourly wage rate of individual $i$ observed in region $r$ at time $t . U_{r t}$ is the unemployment rate in region $r$ at time $t$. $\mu_{r}$ is a region effect, $\lambda_{t}$ is a time effect and $v_{i r t}$ is the remainder error term. $X_{\text {irt }}$ represents control variables which include the characteristics of individual $i$ such as: gender, race, age, age squared, tenure, tenure squared, education, marital status, occupation, industry, sector, and the distinction between urban and rural areas. See the Appendix for a detailed description of these variables for the Brazilian data. The model was estimated using regions fixed effects 2SLS. We instrument the logarithm of unemployment rate in a region $r$ at time $t$ by its lagged value in the previous year, see Baltagi and Blien (1998).

\footnotetext{
${ }^{3}$ It is worth noting that the informality was even higher in 2002, when 37.25\% employees lacked a formal labor contract.
} 
Our paper estimates a wage curve for Brazil using micro-level wage data obtained from the Brazilian National Household Survey at 27 Federative Units over the period 2002 - 2009. After excluding the self-employed or paid family workers, the unemployed, inactive and missing observations, we are left with over 739,490 observations of whom 415,291 are males and 324,199 are females. This rich individual level data set allows us to control for a large set of individual characteristics affecting individuals' wage responses to variations in regional unemployment rates. We are able to investigate the existence of a wage curve for various types of workers: male vs. female, young vs. old, skilled vs. unskilled, formal vs. informal etc.

\section{Empirical Results}

In Table 1 we show the estimation results for the unemployment elasticity of real wages, based on Equation (1). In order to save space, we report only the parameter $\beta$ with its corresponding robust standard error for different types of workers ${ }^{4}$. The unemployment elasticity estimate of the hourly wages for the whole sample is -0.076 and is significant at the $5 \%$ level. Yet, when we sort our sample by gender, we find that the wage curve in Brazil is significant only for the male population. For men, the unemployment elasticity estimate is -0.134 and is significant at the $1 \%$ level. In contrast, the unemployment elasticity estimate for females has the wrong sign (0.002) but is not statistically significant. Our results are in line with the previous findings for Brazil by Santolin and Antigo (2009) or Silva and Monsueto (2012). They are also similar to the results from other South American countries.

The rest of Table 1 confirms the existence of the wage curve for white (-0.077), young (-0.154) and medium skilled workers (-0.110). Also, for workers living in urban areas (-0.055), working for a given employer up to 1 year (-0.180) and between 1 and 5 years (-0.137), and employed in the private sector $(-0.097)$.

\section{Insert Table 1 here}

Having estimated the unemployment elasticities for the whole sample in Table 1, we focus on the differences between males and females in Tables 2 and 3. In Table 2, for the case of men, we estimate a strong and statistically significant unemployment elasticity for black (-0.175),

\footnotetext{
${ }^{4}$ The results on the other control variables are available upon request.
} 
young (-0.190) and medium skilled workers (-0.213). Table 2 shows also that the wages are negatively correlated with local unemployment rates for men living in urban areas (-0.097), working in a given firm up to 1 year (-0.217) and between 1 and 5 years (-0.165), and employed in the private sector $(-0.140)$. For all other categories of workers, the unemployment elasticity is not statistically significant.

Insert Table 2 here

Table 3 shows that for women in Brazil, the wage curve is non-existent. For all categories considered, the unemployment elasticity for women workers is statistically insignificant except for women with 5 or more years of tenure.

Insert Table 3 here

Card (1995) suggests applying subsample specific unemployment rates. Concern over the representativeness of these subsamples should not be an issue for the gender specific unemployment rate. After all, the national labor force surveys, by definition, have to be representative for men and women. We also believe that there are not only econometric but also economic reasons indicating the necessity of differentiating between male and female unemployment. The main one is the enormous difference between the status of men and women in the Brazilian labor market. In some professions, men and women hardly compete for the same jobs.

Figure 1 shows the differences in the unemployment rate between men and women in Brazil over the period 2001 and 2009. It is easy to see that the unemployment rate for men is on average more than 4 percentage points lower than that for women. Moreover, this difference seems to be stable over the period of study.

\section{Insert Figure 1 here}

The wage gap between men and women in the Brazilian labor market is shown in Figure 2. In fact, Figure 2 shows the average hourly wages by gender, calculated using the Brazilian National Household Survey data. Again, the differences between men and women are significant (more than 1 BRL per hour) and persistent over time.

Insert Figure 2 here 
Tables 4 and 5 use gender specific unemployment rates and re-estimate Equation (1) for the subsamples of men and women. Table 4 shows the results for the men subsample. The men's gender specific unemployment elasticity is now significantly lower (-0.093) than that in Table 2 (-0.134). The same applies to particular categories of workers. We find a significant gender specific unemployment elasticity for black (-0.137), young (-0.181) and middle skilled workers $(-0.172)$. In all cases the negative correlation between wages and local unemployment rate is smaller in absolute value than that found in Table 2. Moreover, we observe a negative unemployment elasticity for workers living in rural areas $(-1.110)$ while the previous findings suggested that the wage curve exists for workers living in urban areas only. Finally, we find statistically significant negative unemployment elasticity for men with the lowest and medium tenure level (-0.196 and -0.105 respectively), working both in the private (-0.084) and public ($0.244)$ sectors.

Insert Table 4 here

The impact of gender specific unemployment rates is not significant for the women subsample except for two categories. This includes the youngest women group aged (15-29) with a statistically significant unemployment elasticity of (-0.171). Also, the unemployment elasticity for women with (1-4) years of tenure becomes statistically significant (-0.143).

Insert Table 5 here

The above results seem to confirm important differences between the genders in the Brazilian labor market. They also show that the Brazilian wage curve results are sensitive to the application of gender-specific unemployment rates rather than the total unemployment rate. In this sense they are in line with the ones found in other papers applying gender-specific unemployment rates for the US, Spain, Turkey and Poland, (see Boushey, 2002; Sanroma and Ramos, 2005; Konyali, 2013; and Baltagi and Rokicki, 2014).

\section{Formality of employment}

In this part of the paper, we reassess the Brazilian wage curve, taking into account the formality of employment. We consider a formal worker as one who declares that they have signed a formal contract with the employer. Also, by definition, we restrict our observations to the private sector only. 
It should be noted that informal employment is one of the key characteristics of developing country labor markets. In accordance to the OECD (2009) report, it constitutes almost 50\% of non-agricultural employment in Latin America. Also in Brazil, in spite of its fast economic development in recent years, the share of informal workers still exceeds $25 \%$. Hence, it seems interesting to verify whether wages of informal workers are more or less sensitive to local unemployment rates than their formal counterparts.

Table 6 shows the results of the re-estimated wage Equation (1) with the observations restricted to the private sector only ${ }^{5}$. Not surprisingly, we find evidence of a steeper wage curve for one of the most vulnerable group in the labor market: informal workers. For all workers with informal jobs, the unemployment elasticity is -0.251 and statistically significant at the $1 \%$ confidence interval. The coefficient is even higher in absolute value for males (-0.281), and lower, but still significant for females (-0.189). In contrast, focusing on formal workers, the local unemployment elasticity is not statistically significant.

\section{Insert Table 6 here}

The above results are in line with the findings for other South American countries. In fact, Ramos et al. (2009) find a significant unemployment elasticity for informal workers (-0.179) in Colombia between 2002 and 2006, and an insignificant unemployment elasticity for formal workers $^{6}$. In their study of the wage curve in Uruguay during the 1991-2005 period, Bucheli and González (2012) find a much higher unemployment elasticity for informal workers (-0.241) than their formal counterparts (-0.058). Different results were obtained by Berg and Contreras (2004) for Chile who found lower unemployment elasticity for informal than formal workers during the 1974-1996 period. This could be due to the fact that Berg and Contreras (2004) define self-employed workers as informal workers.

Formal and informal workers can have different observed and unobserved characteristics, which can lead to selection bias in the results. The data available does not allow us to address the effects of unobserved characteristics. However, following Baltagi et al. (2013), we can

\footnotetext{
${ }^{5}$ The control variables are exactly the same as in previous regressions.

${ }^{6}$ Contrary to our results, Ramos et al. (2009) also find that the unemployment elasticity for women working in the informal sector is higher than that for men in Colombia.
} 
explore the differences between formal and informal workers with similar observable characteristics, and check how sensible the results are for potential selection bias ${ }^{7}$ using a twostep approach. First, we estimate a probit model in order to calculate the probability of being a formal worker, conditional on gender, race, age, household type, education, place of living, tenure, occupation and industry. In the second step we use the estimated probabilities of being an informal worker in the estimation of Equation (1) for two different groups of workers: workers with probability of being formal above the median and workers with probability of been formal below the median.

The results of the first step estimation are summarized in Table 7. Here, the dependent variable takes the value one if the worker has a formal contract and zero otherwise. As expected, being a female and having children reduces the probability of having a formal job. On the other hand, the probability of being a formal worker increases with age, tenure, and is monotonically increasing with years of education. Also workers living in cities are more likely to have formal employment than their counterparts inhabiting rural areas.

\section{Insert Table 7 here}

Using the probit results, we predict the probability of being formal for each individual in the data set. Then, we re-estimate the wage curve for two groups of workers: the one with probability of being formal above the median and another with the probability below the median. Table 8 shows the estimation results. We find that workers with probability of being formal either above or below the median probability face completely different wage curves. As a matter of fact, only for those with probability below the median the negative relation between wages and local unemployment rate is strong and statistically significant. Within that group, informal workers not surprisingly face a steeper wage curve ( -0.305 compared to -0.129 for formal workers). The elasticity of unemployment for informal workers with probability of being formal above the median is also negative $(-0.086)$ but not statistically significant. In the case of their formal counterparts the coefficient is not statistically significant.

\footnotetext{
${ }^{7}$ As explained by Baltagi et al. (2013), correcting the Mincerian equation using Heckman’s procedure is difficult here because we can think of no variable that helps explain informality that is at the same time irrelevant for explaining wages.
} 
Insert Table 8 here

These results are close to Baltagi et al. (2013) for Turkey who explain the difference between formal and informal elasticities in two ways: i) there are unobserved differences in productivity between the groups; and ii) workers in the informal market face lower wages when the economic activity declines. In the case of Brazil (and many other countries), the second explanation has a key component: the high termination cost. Brazilian Labor Law guarantees a set of benefits to employees in the case of unfair contract termination (when it is not a workers fault). ${ }^{8}$ This in turn makes formal employment less flexible through times of economic volatility, which guarantees employment stability but on the other hand provide more incentives for informal activities that try to avoid these costs.

\section{Conclusion}

This paper reconsiders the Brazilian wage curve using individual data from the Brazilian National Household Survey ${ }^{9}$ at 27 Federative Units over the period 2002 - 2009. We find evidence in favor of the Brazilian wage curve with an unemployment elasticity of -0.08 when the lagged unemployment rate is used as an instrument for current unemployment rate. We also find that males in Brazil are significantly more responsive to local unemployment rates $(-0.13)$ than their female counterparts. In fact, we find that the unemployment elasticity for women is statistically insignificant. Applying gender specific unemployment rates, the elasticity for men decreases to -0.09 , while the elasticity for women remains statistically insignificant.

This paper also finds that the Brazilian wage curve is completely different in the case of formal and informal workers. Our results show that the unemployment elasticity for informal workers is high (-0.251) and statistically significant. While it is statistically insignificant for formal workers. We also estimate the probability of being a formal worker, and find that for those workers with probability of being formal below the median, the unemployment elasticity estimate for the informal workers is higher in absolute value than its formal counterpart (-0.305 compared to -0.129).

\footnotetext{
${ }^{8}$ Fair reasons can be bad discipline, insubordination, employment abandonment, criminal acts, etc.

${ }^{9}$ In portuguese “Pesquisa Nacional por Amostra de Domicílios” (PNAD).
} 
The results presented here highlight important facts about the Brazilian labor market: informal and low paid jobs are one of the most vulnerable groups especially for males. As explained by Bertrand (2011) women are more risk-averse than men and in general seek occupations with more stable earnings that also pay less on average. Therefore, despite the higher participation of women in the informal market and higher unemployment rates, the occupations they choose are more stable and less susceptible to the wage curve regularities. The opposite happens with men who are less risk-averse and tend to have less stable jobs and consequently a higher unemployment elasticity, especially when these are informal jobs. 


\section{References:}

Arango, L. E., Obando, N., Posada, C. E., 2010. Sensibilidad de los Salarios al Desempleo Regional en Colombia: Nuevas Estimaciones de la Curva de Salarios. Borradores de Economía 590.

Baltagi, B. H., Blien, U., 1998. The German wage curve: evidence from the IAB employment sample. Economics Letters 61, 135-142.

Baltagi, B. H., Baskaya, Y. S., Hulagu, T., 2013. How different are the wage curves for formal and informal workers? Evidence from Turkey. Papers in Regional Science 92 (2), 271-283.

Baltagi, B. H., Rokicki, B., 2014. The Spatial Polish Wage Curve with Gender Effects: Evidence from the Polish Labor Survey. Regional Science and Urban Economics 49, 36-47.

Barros, R., P. Olinto, T. Lunde, Carvalho, M., 2011. The Impact of Access to Free Childcare on Women's Labor Market Outcomes: Evidence from a Randomized Trial in Low-income Neighborhoods of Rio de Janeiro. Paper prepared for the World Bank Economists' Forum.

Berg, J., Contreras, D., 2004. Political-Economic Regime and the Wage Curve: Evidence from Chile, 1957-96. International Review of Applied Economics 18(2), 151-165.

Bertrand, M., 2011. New perspectives on gender. Handbook of labor economics 4, 1543-1590.

Blanchflower, D.G., Oswald, A.J., 1990. The wage curve. Scandinavian Journal of Economics 92, 215-235.

Blanchflower, D.G., Oswald, A.J., 1995. An introduction to the wage curve. Journal of Economic Perspectives 9, 153-167.

Blanchflower, D.G., Oswald, A.J., 2000. International wage curves. [In:] Differences and Changes in Wage Structures, edited by Richard Freeman and Larry Katz, University of Chicago Press and NBER.

Blanchflower, D.G., Oswald, A.J., 2005. The wage curve reloaded. NBER Working Paper Series, Vol. w11338. Available at SSRN: http://ssrn.com/abstract=723307

Boushey, H., 2002. Reworking the Wage Curve: Exploring the consistency of the model across time, space and demographic group. Review of Political Economy 14(3), 293-311.

Bucheli, M., González, C., 2012. An Estimation of the Wage Curve for Uruguay. Cuadernos de Economía 31(56), 261-279.

Card, D., 1995. The Wage Curve: A Review. Journal of Economic Literature 33, 285-299.

Corseuil, C. H., Foguel, M. N., 2002. An Alternative Income Deflator for some Brazilian Household Surveys. Discussion Paper 897.

Galiani, S., 1999. Wage Determination in Argentina: An Econometric Analysis with 
Methodology Discussion. University Torcuato Di Tella, Buenos Aires, mimeo.

Mincer, J. A. (1974). Schooling, experience, and earnings. NBER Books.

Garcia, L. L., 2002. A curva de salário para o Brasil: uma análise microeconométrica a partir dos dados da PNAD de 1981 a 1999. Belo Horizonte: UFMG/Cedeplar.

García, P., Granados, P., 2005. La Curva de Salarios en Chile. Central Bank of Chile, Working Paper 320.

Konyali, G., 2012. Wage Curve Evidence from Turkey’s 2007-2009 Income and Living Conditions Survey. Investigaciones Regionales 24, 199-210.

Nijkamp, P., Poot, J., 2005. The Last Word on the Wage Curve? Journal of Economic Surveys 19(3), 421-450.

OECD, 2009. Is Informal Normal? Towards More and Better Jobs in Developing Countries. Jutting, J., de Laiglesia J.R. (eds.), OECD Development Centre Studies, Paris.

Ramos, R., Duque, J. C., Surinach, J., 2009. Is the Wage Curve Formal or Informal? Evidence for Colombia. Research Institute of Applied Economics, Working Paper 2009/18.

Reis, M. C., 2006. Os Impactos das Mudanças na Demanda por Trabalho Qualificado sobre o Desemprego por Nível de Qualificação durante os Anos Noventa no Brasil. Revista Brasileira de Economia 60(3), 297-319.

Sanroma, E., Ramos, R., 2005. Further Evidence on Disaggregated Wage Curves: The Case of Spain. Australian Journal of Labour Economics 8(3), 227-243.

Santolin, R., Antigo, M. F., 2009. Curvas de Salários Dinâmicas: Um Estudo dos Determinantes da Histerese do Desemprego no Brasil. Belo Horizonte: UFMG/Cedeplar.

Silva, A. S. P. Monsueto, S. E., 2012. Flexibilidade do Mercado de Trabalho: Uma Análise Comparativa Entre Segmentos Socioeconômicos no Brasil (2002-2009). Available at: http://www.anpec.org.br/encontro/2012/inscricao/files_//i12-351de703e4da2073e562 bebdf5fd0981.pdf

Souza, I., Machado, A., 2004. Curva de Rendimentos: uma Análise no Mercado de Trabalho Urbano e Rural no Brasil (1981/99). Revista de Economia e Sociologia Rural 42(1), 35-54.

The World Bank Group, 2014. Gender at work: a companion to the World Development Report on Jobs. The World Bank. 


\section{Data Appendix}

The data set used in the present study is based on the National Household Survey (from Portuguese PNAD - Pesquisa Nacional por Amostra de Domicílios) for the period 2002-2009. After excluding the self-employed or paid family workers, the unemployed, inactive and missing observations, we are left with over 739,490 observations. The data provides representative information on the state level where the employee is located.

In this study we use individual hourly wage deflated by an index especially developed by Corseuil and Foguel (2002) for this survey and updated each year by the Brazilian Institute of Geography and Statistics (from Portuguese IBGE - Instituto Brasiliero de Geografia e Estatística). We also calculated the unemployment rate at the state level for each year.

The control variables used in the regressions are the following:

- Age of the individual

- $\quad$ Gender. Female $=1$ and male $=0$.

- $\quad$ Race. Black $=1$ and white $=0$

- Household type. This variable includes 4 categories: couple without children $=1$; couple with children $=2$; single mother with children $=3$; other household types $=4$.

- Education. This variable includes 4 different categories: up to 7 years of education $=1$; more than 7 and up to 10 years of education $=2$; more than 10 and up to 14 years of education $=3$; 15 or more years of education $=4$.

- The individual's years of tenure at the firm.

- Regions. We distinguish among the 27 states of Brazil, also called Federative Units (UF).

- Occupation. This variable includes 9 categories: managers; professionals in the sciences and arts; technicians; administrative workers; service workers; vendors and trade service providers; agricultural workers; workers producing goods and services, and repair and maintenance; members of the armed forces and auxiliary.

- Industry classification. This variable includes 12 categories: agricultural; other industrial activities; manufacturing industry; construction; trade and repair; accommodation and food; transport, storage and communication; public administration; 
education, health and social services; domestic services; other community, social and personal services; other activities.

- Formality of employment. Formal employee $=1$ and informal employee $=0$.

- Sector. Public $=1$ and private $=0$.

\section{Summary statistics}

$\begin{array}{lccccc}\text { Variable } & \text { Observations } & \text { Mean } & \text { Std. Dev. } & \text { Min } & \text { Max } \\ & & & & \\ \text { Year } & 739490 & 2005.688 & 2.270173 & 2002 & 2009 \\ \text { Urban/rural areas } & 739490 & 0.908660 & 0.288092 & 0 & 1 \\ \text { Hourly wage } & 739490 & 4.455756 & 2.792494 & 1.5 & 15 \\ \text { Unemployment rate } & 739490 & 8.468754 & 2.258912 & 3.75 & 20.36 \\ \text { Working hours weekly } & 739490 & 41.23837 & 9.250804 & 10 & 60 \\ \text { Age } & 739490 & 34.12132 & 11.55742 & 15 & 75 \\ \text { Gender } & 739490 & 0.438409 & 0.496192 & 0 & 1 \\ \text { Race } & 739490 & 0.518010 & 0.499676 & 0 & 1 \\ \text { Tenure } & 739490 & 5.115286 & 6.790269 & 0 & 60 \\ \text { Sector } & 739490 & 0.103849 & 0.305064 & 0 & 1 \\ \text { Formality of employment } & 739490 & 0.680597 & 0.466246 & 0 & 1\end{array}$


Figure 1: Unemployment in Brazil by Gender, 2001-2009 (in \%)

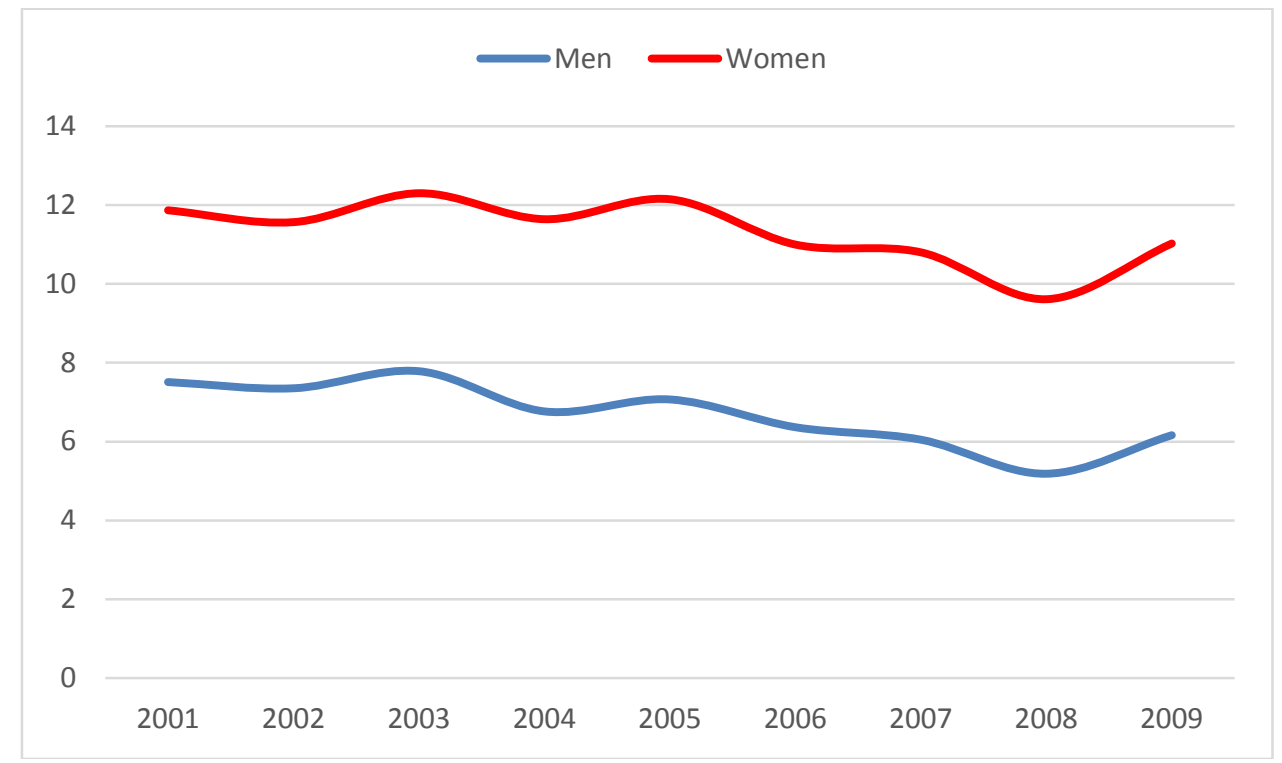

Source: This is based on data from the National Household Survey

Figure 2: Hourly wages in Brazil by Gender, 2001-2009 (in BRL)

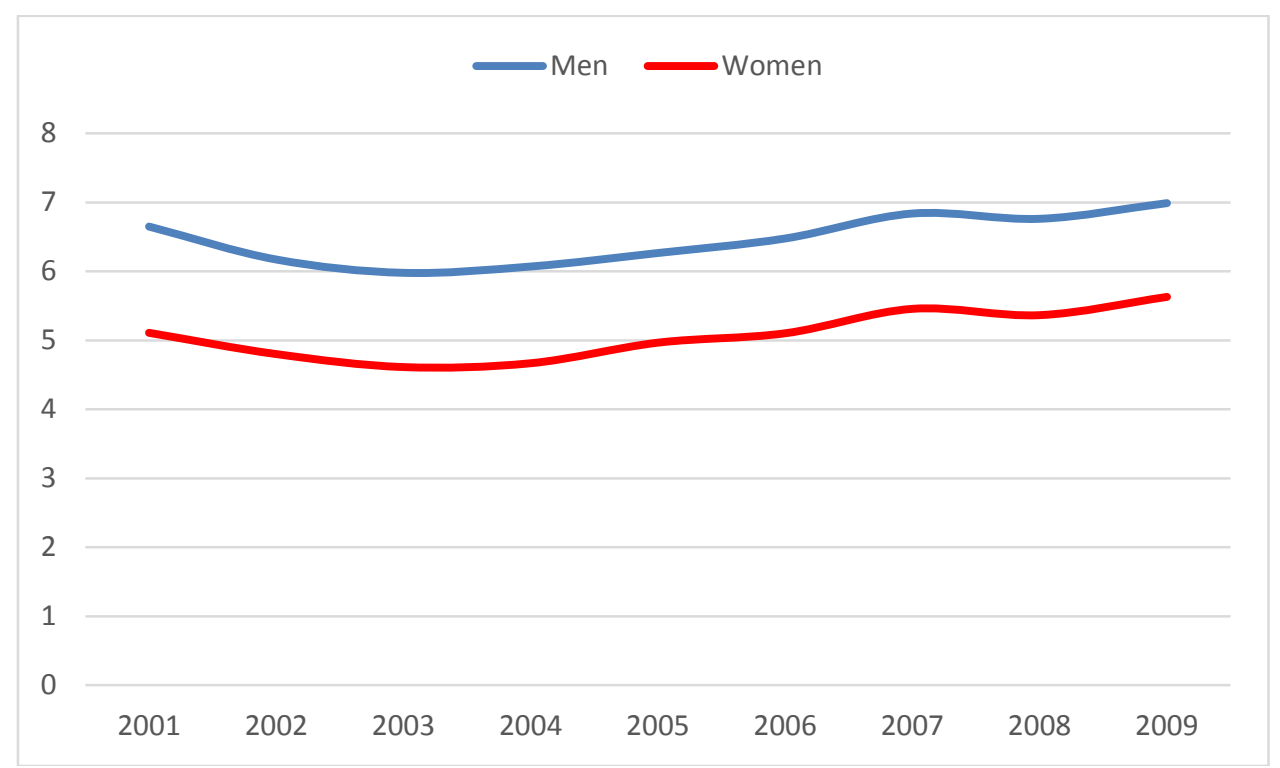

Source: This is based on data from the National Household Survey 
Table 1

The Brazilian unemployment elasticity of real hourly wages by worker type

\begin{tabular}{|c|c|c|c|c|c|c|c|c|c|c|c|c|}
\hline & All workers & men & women & \multicolumn{2}{|c|}{ White } & Black & $\begin{array}{l}\text { Age } \\
15-29\end{array}$ & $\begin{array}{l}\text { Age } \\
30-44\end{array}$ & $\begin{array}{l}45 \text { and } \\
\text { older }\end{array}$ & $\begin{array}{l}\text { Low } \\
\text { skill }\end{array}$ & $\begin{array}{l}\text { Medium } \\
\text { skill }\end{array}$ & $\begin{array}{l}\text { High } \\
\text { skill }\end{array}$ \\
\hline FE- 2SLS & $\begin{array}{c}-0.076 * * \\
(0.033)\end{array}$ & $\begin{array}{c}-0.134 * * * \\
(0.043)\end{array}$ & $\begin{array}{c}0.002 \\
(0.049)\end{array}$ & \multicolumn{2}{|c|}{$\begin{array}{l}-0.077^{*} \\
(0.040)\end{array}$} & $\begin{array}{l}-0.074 \\
(0.053)\end{array}$ & $\begin{array}{c}-0.154 * * * \\
(0.048)\end{array}$ & $\begin{array}{l}-0.030 \\
(0.053)\end{array}$ & $\begin{array}{c}0.051 \\
(0.080)\end{array}$ & $\begin{array}{l}-0.048 \\
(0.049)\end{array}$ & $\begin{array}{c}-0.110^{* *} \\
(0.046)\end{array}$ & $\begin{array}{r}0.030 \\
(0.135)\end{array}$ \\
\hline $\begin{array}{c}\text { R-squared } \\
\text { Observations }\end{array}$ & $\begin{array}{c}0.47 \\
739,490\end{array}$ & $\begin{array}{c}0.45 \\
415,291\end{array}$ & $\begin{array}{c}0.50 \\
324,199\end{array}$ & \multicolumn{2}{|c|}{$\begin{array}{c}0.46 \\
356,427\end{array}$} & $\begin{array}{c}0.43 \\
383,063\end{array}$ & $\begin{array}{c}0.42 \\
306,236\end{array}$ & $\begin{array}{c}0.48 \\
285,725\end{array}$ & $\begin{array}{c}0.48 \\
147,529\end{array}$ & $\begin{array}{c}0.28 \\
268,948\end{array}$ & $\begin{array}{c}0.39 \\
418,696\end{array}$ & $\begin{array}{c}0.21 \\
51,846\end{array}$ \\
\hline FE- 2SLS & $\begin{array}{l}\text { Rural } \\
-0.346 \\
(0.525)\end{array}$ & $\begin{array}{l}\text { Urban } \\
-0.055^{*} \\
(0.033)\end{array}$ & \multicolumn{3}{|c|}{$\begin{array}{c}-0.180 * * \\
(0.070)\end{array}$} & $\begin{array}{l}137^{* * *} \\
(0.048)\end{array}$ & $\begin{array}{c}\text { Tenure }>=5 \\
0.082 \\
(0.057)\end{array}$ & $\begin{array}{c}\text { Private } \\
-0.097 * * * \\
(0.034)\end{array}$ & $\begin{array}{c}\text { Public } \\
\\
-0.003 \\
(0.105)\end{array}$ & & & \\
\hline $\begin{array}{c}\text { R-squared } \\
\text { Observations }\end{array}$ & $\begin{array}{c}0.41 \\
67,545\end{array}$ & $\begin{array}{c}0.46 \\
671,945\end{array}$ & \multicolumn{3}{|c|}{$\begin{array}{c}0.35 \\
180,449\end{array}$} & $\begin{array}{c}0.42 \\
300,434\end{array}$ & $\begin{array}{c}0.50 \\
258,607\end{array}$ & $\begin{array}{c}0.42 \\
662,695\end{array}$ & $\begin{array}{c}0.42 \\
76,795\end{array}$ & & & \\
\hline
\end{tabular}

Notes:

a) See the Appendix for sample coverage.

b) Robust standard errors in parentheses. *, ** and *** represent significance at $10 \%, 5 \%$ and $1 \%$, respectively.

c) Low skill workers refer to individuals with 0 to 7 years of education. Medium skill workers refer to individuals with 8 to 14 years of education. High skill workers refer to

15 and more years of education.

d) FE-2SLS uses the logarithm of unemployment rate by region in the previous year as an instrument for the logarithm of unemployment rate by region at time t. 
Table 2

The Brazilian men unemployment elasticity of real hourly wages by worker type

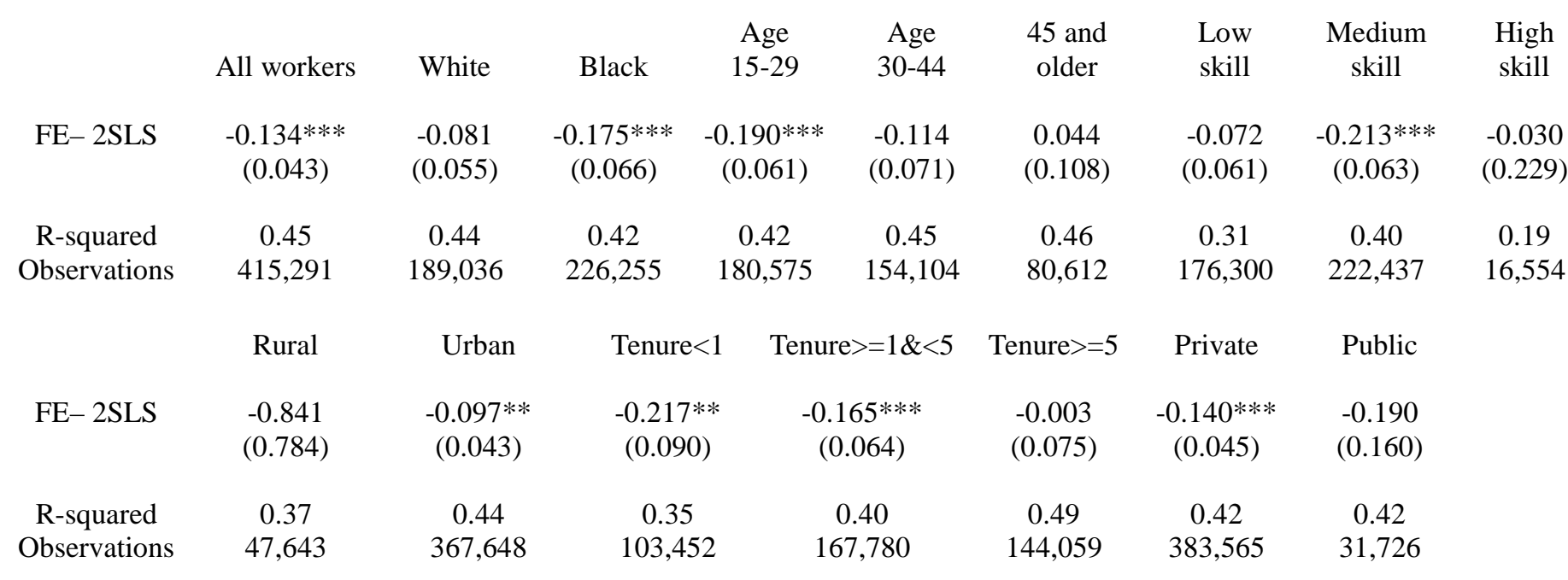

Notes:

a) See the Appendix for sample coverage.

b) Robust standard errors in parentheses. *, ** and *** represent significance at $10 \%, 5 \%$ and $1 \%$, respectively.

c) Low skill workers refer to individuals with 0 to 7 years of education. Medium skill workers refer to individuals with 8 to 14 years of education. High skill workers refer to

15 and more years of education.

d) FE-2SLS uses the logarithm of unemployment rate by region in the previous year as an instrument for the logarithm of unemployment rate by region at time t. 
Table 3

The Brazilian women unemployment elasticity of real hourly wages by worker type

\begin{tabular}{|c|c|c|c|c|c|c|c|c|c|}
\hline & All workers & White & Black & $\begin{array}{c}\text { Age } \\
15-29\end{array}$ & $\begin{array}{c}\text { Age } \\
30-44\end{array}$ & $\begin{array}{l}45 \text { and } \\
\text { older }\end{array}$ & $\begin{array}{l}\text { Low } \\
\text { skill }\end{array}$ & $\begin{array}{l}\text { Medium } \\
\text { skill }\end{array}$ & $\begin{array}{l}\text { High } \\
\text { skill }\end{array}$ \\
\hline FE- 2SLS & $\begin{array}{c}0.002 \\
(0.049)\end{array}$ & $\begin{array}{c}-0.074 \\
(0.057)\end{array}$ & $\begin{array}{c}0.096 \\
(0.087)\end{array}$ & $\begin{array}{l}-0.095 \\
(0.075)\end{array}$ & $\begin{array}{c}0.074 \\
(0.078)\end{array}$ & $\begin{array}{c}0.067 \\
(0.117)\end{array}$ & $\begin{array}{c}-0.016 \\
(0.079)\end{array}$ & $\begin{array}{c}0.019 \\
(0.066)\end{array}$ & $\begin{array}{r}0.070 \\
(0.166)\end{array}$ \\
\hline $\begin{array}{c}\text { R-squared } \\
\text { Observations }\end{array}$ & $\begin{array}{c}0.50 \\
324,199\end{array}$ & $\begin{array}{c}0.50 \\
167,391\end{array}$ & $\begin{array}{c}0.46 \\
156,808\end{array}$ & $\begin{array}{c}0.44 \\
125,661\end{array}$ & $\begin{array}{c}0.52 \\
131,621\end{array}$ & $\begin{array}{c}0.52 \\
66,917\end{array}$ & $\begin{array}{c}0.20 \\
92,648\end{array}$ & $\begin{array}{c}0.38 \\
196,259\end{array}$ & $\begin{array}{c}0.23 \\
35,292\end{array}$ \\
\hline & Rural & Urban & Tenure $<1$ & \multicolumn{2}{|c|}{ Tenure $>=1 \&<5$} & Tenure $>=5$ & Private & Public & \\
\hline FE- 2SLS & $\begin{array}{c}0.513 \\
(0.661)\end{array}$ & $\begin{array}{c}0.000 \\
(0.050)\end{array}$ & $\begin{array}{l}-0.143 \\
(0.110)\end{array}$ & \multicolumn{2}{|c|}{$\begin{array}{c}-0.110 \\
(0.070)\end{array}$} & $\begin{array}{c}0.210^{* *} \\
(0.087)\end{array}$ & $\begin{array}{l}-0.040 \\
(0.053)\end{array}$ & $\begin{array}{c}0.208 \\
(0.136)\end{array}$ & \\
\hline $\begin{array}{c}\text { R-squared } \\
\text { Observations }\end{array}$ & $\begin{array}{c}0.43 \\
19,902\end{array}$ & $\begin{array}{c}0.50 \\
304,297\end{array}$ & 0.38 & & 132,654 & $\begin{array}{c}0.52 \\
114,548\end{array}$ & $\begin{array}{c}0.43 \\
279,130\end{array}$ & $\begin{array}{c}0.44 \\
45,069\end{array}$ & \\
\hline
\end{tabular}

Notes:

a) See the Appendix for sample coverage.

b) Robust standard errors in parentheses. *, ** and *** represent significance at $10 \%, 5 \%$ and $1 \%$, respectively.

c) Low skill workers refer to individuals with 0 to 7 years of education. Medium skill workers refer to individuals with 8 to 14 years of education. High skill workers refer to

15 and more years of education.

d) FE-2SLS uses the logarithm of unemployment rate by region in the previous year as an instrument for the logarithm of unemployment rate by region at time t. 
Table 4

The Brazilian men unemployment elasticity of real hourly wages by worker type - gender specific unemployment rate

\begin{tabular}{|c|c|c|c|c|c|c|c|c|c|c|}
\hline & All workers & White & Black & \multicolumn{2}{|c|}{$\begin{array}{c}\text { Age } \\
15-29\end{array}$} & $\begin{array}{c}\text { Age } \\
30-44\end{array}$ & $\begin{array}{c}45 \text { and } \\
\text { older }\end{array}$ & $\begin{array}{l}\text { Low } \\
\text { skill }\end{array}$ & $\begin{array}{l}\text { Medium } \\
\text { skill }\end{array}$ & $\begin{array}{l}\text { High } \\
\text { skill }\end{array}$ \\
\hline FE- 2SLS & $\begin{array}{c}-0.093^{* *} \\
(0.038)\end{array}$ & $\begin{array}{l}-0.062 \\
(0.052)\end{array}$ & $\begin{array}{c}-0.137 * * \\
(0.055)\end{array}$ & \multicolumn{2}{|c|}{$\begin{array}{c}-0.181 * * * \\
(0.053)\end{array}$} & $\begin{array}{l}-0.017 \\
(0.062)\end{array}$ & $\begin{array}{c}0.028 \\
(0.095)\end{array}$ & $\begin{array}{l}-0.035 \\
(0.054)\end{array}$ & $\begin{array}{c}-0.172 * * * \\
(0.054)\end{array}$ & $\begin{array}{l}-0.122 \\
(0.220)\end{array}$ \\
\hline $\begin{array}{c}\text { R-squared } \\
\text { Observations }\end{array}$ & $\begin{array}{c}0.45 \\
415,291\end{array}$ & $\begin{array}{c}0.44 \\
189,036\end{array}$ & $\begin{array}{c}0.42 \\
226,255\end{array}$ & \multicolumn{2}{|c|}{$\begin{array}{c}0.42 \\
180,575\end{array}$} & $\begin{array}{c}0.45 \\
154,104\end{array}$ & $\begin{array}{c}0.46 \\
80,612\end{array}$ & $\begin{array}{c}0.31 \\
176,300\end{array}$ & $\begin{array}{c}0.40 \\
222,437\end{array}$ & $\begin{array}{c}0.19 \\
16,554\end{array}$ \\
\hline FE- 2SLS & $\begin{array}{c}-1.110 * \\
(0.653)\end{array}$ & $\begin{array}{c}-0.056 \\
(0.038)\end{array}$ & $\begin{array}{c}-0.196 * * \\
(0.077)\end{array}$ & Tenure $<1$ & \multicolumn{2}{|c|}{$\begin{array}{c}-0.105^{*} \\
(0.055)\end{array}$} & $\begin{array}{c}\text { Tenure }>=5 \\
0.032 \\
(0.068)\end{array}$ & $\begin{array}{c}\text { Private } \\
-0.084^{* *} \\
(0.039)\end{array}$ & $\begin{array}{c}-0.244^{*} \\
(0.128)\end{array}$ & \\
\hline $\begin{array}{c}\text { R-squared } \\
\text { Observations }\end{array}$ & $\begin{array}{c}0.37 \\
47,643\end{array}$ & $\begin{array}{c}0.44 \\
367,648\end{array}$ & \multicolumn{2}{|c|}{$\begin{array}{c}0.35 \\
103.452\end{array}$} & \multicolumn{2}{|c|}{0.41} & $\begin{array}{c}0.49 \\
144,059\end{array}$ & $\begin{array}{c}0.42 \\
383,565\end{array}$ & $\begin{array}{c}0.42 \\
31,726\end{array}$ & \\
\hline
\end{tabular}

Notes:

a) See the Appendix for sample coverage.

b) Robust standard errors in parentheses. *, ** and *** represent significance at $10 \%, 5 \%$ and $1 \%$, respectively.

c) Low skill workers refer to individuals with 0 to 7 years of education. Medium skill workers refer to individuals with 8 to 14 years of education. High skill workers refer to

15 and more years of education.

d) FE-2SLS uses the logarithm of unemployment rate by region in the previous year as an instrument for the logarithm of unemployment rate by region at time t. 
Table 5

The Brazilian women unemployment elasticity of real hourly wages by worker type - gender specific unemployment rate

\begin{tabular}{|c|c|c|c|c|c|c|c|c|c|}
\hline & All workers & White & Black & $\begin{array}{c}\text { Age } \\
15-29\end{array}$ & $\begin{array}{c}\text { Age } \\
30-44\end{array}$ & $\begin{array}{l}45 \text { and } \\
\text { older }\end{array}$ & $\begin{array}{l}\text { Low } \\
\text { skill }\end{array}$ & $\begin{array}{l}\text { Medium } \\
\text { skill }\end{array}$ & $\begin{array}{l}\text { High } \\
\text { skill }\end{array}$ \\
\hline FE- 2SLS & $\begin{array}{l}-0.015 \\
(0.060)\end{array}$ & $\begin{array}{l}-0.103 \\
(0.073)\end{array}$ & $\begin{array}{c}0.112 \\
(0.100)\end{array}$ & $\begin{array}{c}-0.171 * \\
(0.093)\end{array}$ & $\begin{array}{c}0.068 \\
(0.096)\end{array}$ & $\begin{array}{c}0.141 \\
(0.134)\end{array}$ & $\begin{array}{l}-0.014 \\
(0.099)\end{array}$ & $\begin{array}{c}0.016 \\
(0.080)\end{array}$ & $\begin{array}{l}-0.054 \\
(0.190)\end{array}$ \\
\hline $\begin{array}{c}\text { R-squared } \\
\text { Observations }\end{array}$ & $\begin{array}{c}0.50 \\
324,199\end{array}$ & $\begin{array}{c}0.50 \\
167,391\end{array}$ & $\begin{array}{c}0.46 \\
156,808\end{array}$ & $\begin{array}{c}0.44 \\
125,661\end{array}$ & $\begin{array}{c}0.52 \\
131,621\end{array}$ & $\begin{array}{c}0.52 \\
66,917\end{array}$ & $\begin{array}{c}0.20 \\
92,648\end{array}$ & $\begin{array}{c}0.38 \\
196,259\end{array}$ & $\begin{array}{c}0.23 \\
35,292\end{array}$ \\
\hline & Rural & Urban & Tenure $<1$ & \multicolumn{2}{|c|}{ Tenure $>=1 \&<5$} & Tenure $>=5$ & Private & Public & \\
\hline FE- 2SLS & $\begin{array}{c}0.393 \\
(0.446)\end{array}$ & $\begin{array}{c}-0.022 \\
(0.061)\end{array}$ & $\begin{array}{c}-0.130 \\
(0.149)\end{array}$ & \multicolumn{2}{|c|}{$\begin{array}{c}-0.143^{*} \\
(0.086)\end{array}$} & $\begin{array}{c}0.156 \\
(0.099)\end{array}$ & $\begin{array}{c}-0.077 \\
(0.064)\end{array}$ & $\begin{array}{c}0.161 \\
(0.155)\end{array}$ & \\
\hline $\begin{array}{c}\text { R-squared } \\
\text { Observations }\end{array}$ & $\begin{array}{c}0.43 \\
19,902\end{array}$ & $\begin{array}{c}0.50 \\
304,297\end{array}$ & $\begin{array}{c}0.38 \\
76.997\end{array}$ & \multicolumn{2}{|c|}{0.44} & $\begin{array}{c}0.52 \\
114,548\end{array}$ & $\begin{array}{c}0.43 \\
279,130\end{array}$ & $\begin{array}{c}0.44 \\
45,069\end{array}$ & \\
\hline
\end{tabular}

Notes:

a) See the Appendix for sample coverage.

b) Robust standard errors in parentheses. *, ** and *** represent significance at $10 \%, 5 \%$ and $1 \%$, respectively.

c) Low skill workers refer to individuals with 0 to 7 years of education. Medium skill workers refer to individuals with 8 to 14 years of education. High skill workers refer to

15 and more years of education.

d) FE-2SLS uses the logarithm of unemployment rate by region in the previous year as an instrument for the logarithm of unemployment rate by region at time t. 
Table 6

The Brazilian unemployment elasticity of real hourly wages by formality of employment

\begin{tabular}{|c|c|c|c|c|c|c|c|c|c|}
\hline & \multicolumn{3}{|c|}{ Both genders } & \multicolumn{3}{|c|}{ Men } & \multicolumn{3}{|c|}{ Women } \\
\hline & All & Informal & Formal & All & Informal & Formal & All & Informal & Formal \\
\hline FE- 2SLS & $\begin{array}{c}-0.095 * * * \\
(0.034)\end{array}$ & $\begin{array}{c}-0.251^{* * *} \\
(0.059)\end{array}$ & $\begin{array}{c}-0.016 \\
(0.041)\end{array}$ & $\begin{array}{c}-0.148^{* * *} \\
(0.044)\end{array}$ & $\begin{array}{c}-0.281 * * * \\
(0.080)\end{array}$ & $\begin{array}{c}-0.074 \\
(0.053)\end{array}$ & $\begin{array}{c}-0.036 \\
(0.053)\end{array}$ & $\begin{array}{c}-0.189 * * \\
(0.089)\end{array}$ & $\begin{array}{c}0.070 \\
(0.064)\end{array}$ \\
\hline $\begin{array}{c}\text { R-squared } \\
\text { Observations }\end{array}$ & 0.42 & 0.36 & 0.43 & 0.43 & $\begin{array}{c}0.38 \\
127.407\end{array}$ & 0.41 & $\begin{array}{c}0.43 \\
270.130\end{array}$ & $\begin{array}{c}0.35 \\
108780\end{array}$ & $\begin{array}{c}0.46 \\
0\end{array}$ \\
\hline Observations & 662,695 & 236,195 & 426,500 & 383,565 & 127,407 & 256,158 & 279,130 & 108,788 & 170,342 \\
\hline
\end{tabular}

Notes:

a) See the Appendix for sample coverage.

b) Robust standard errors in parentheses. *, ** and *** represent significance at $10 \%, 5 \%$ and $1 \%$, respectively.

c) FE-2SLS uses the logarithm of unemployment rate by region in the previous year as an instrument for the logarithm of unemployment rate by region at time t. 


\section{Table 7}

The formality status determinants

\begin{tabular}{lc}
\multicolumn{1}{c}{ Variables } & Coefficients \\
\hline \multirow{2}{*}{ Women } & $-0.091^{* * *}$ \\
& $(0.004)$ \\
Black & 0.005 \\
& $(0.004)$ \\
Age & $0.102^{* * *}$ \\
Age2 & $(0.001)$ \\
& $-0.001^{* * *}$ \\
Couple with children & $(0.000)$ \\
& $-0.106^{* * *}$ \\
Single mother with children & $(0.006)$ \\
& $-0.190^{* * *}$ \\
Other household type & $(0.007)$ \\
& $-0.144^{* * *}$ \\
8-10 years of education & $(0.007)$ \\
& $0.149^{* * *}$ \\
11-14 years of education & $(0.005)$ \\
& $0.428^{* * *}$ \\
15 years or more of education & $(0.005)$ \\
& $0.434^{* * *}$ \\
Urban & $(0.010)$ \\
Tenure & $0.165^{* * *}$ \\
Tenure2 & $(0.006)$ \\
& $0.056^{* * *}$ \\
Observations & $(0.001)$ \\
& $-0.002^{* * *}$ \\
& $(0.000)$ \\
& 662,695 \\
&
\end{tabular}

Notes:

a) Marginal effects estimated with probit.

b) Robust standard errors in parentheses. *, ** and ${ }^{* * *}$ represent significance at $10 \%, 5 \%$ and $1 \%$, respectively.

c) Other control variables include occupation, industry, year and region dummies.

d) Omitted categories for household status and education are couples without children and less than 8 year of education, respectively. 


\section{Table 8}

The Brazilian unemployment elasticity of real hourly wages by formality status and propensity scores

\section{FE-2SLS}

$\begin{array}{lcc}\text { Propensity scores } & \begin{array}{c}\text { Informal } \\ \text { worker }\end{array} & \begin{array}{c}\text { Formal } \\ \text { worker }\end{array} \\ \text { Below median } & -0.305 * * * & -0.129 * * \\ & & \\ \text { Above median } & (0.068) & (0.064) \\ & -0.086 & 0.062 \\ & (0.125) & (0.053)\end{array}$

Notes:

a) FE-2SLS uses the logarithm of unemployment rate by region in the previous year as an instrument for the logarithm of unemployment rate by region at time t.

b) Robust standard errors in parentheses. *, ** and *** represent significance at $10 \%, 5 \%$ and $1 \%$, respectively.

c) The control variables are exactly the same as in previous tables. 